\title{
Printing for the Reformation: The Canonical Documents of the Edwardian Church of England,
} 1547-1553

\author{
Celyn Richards
}

The Council are always intent upon consolidating

the new doctrine by the dissemination of new books

FRANÇOIS VAN DER DELFT, Imperial ambassador in London, to Charles V on 29 May $1547^{1}$

The reign of Edward vi ushered in a period of defiant evangelicalism in England. Imperial ambassador François van der Delft wrote to Charles v in worried tones just months into the reign about the surging evangelicalism that followed Edward's accession. The publication and compulsory provision of new official church documents spearheaded the Edwardian reformation. ${ }^{2}$ Between 1547 and 1553, the regime introduced five new official publications to be purchased by every parish church in the realm: Archbishop Cranmer's Homilies and Erasmus' Paraphrases (31 July 1547), the Order of Communion and the Catechism (8 March 1548), and the Book of Common Prayer (January 1549 and November $\left.155^{2}\right) .^{3}$ These publications, along with the Henrician Great

1 Quote taken from Martin A.S. Hume and Royall Tyler (eds.), Calendar of Letters, Despatches and State Papers relating to the negotiations between England and Spain in the Archives of Simancas and Elsewhere (9 vols., London: H.M. Stationery Office, 1862-1912), pp. 90-93. This paper is derived from a doctoral thesis completed at Durham University, funded by the Arts and Humanities Research Council, via the Northern Bridge doctoral training partnership and the International Placement Scheme. Research was conducted at the Huntington Library, San Marino California.

2 John Craig, 'Erasmus or Calvin? The Politics of Book Purchase in the Early Modern English Parish', in Polly Ha and Patrick Collinson (eds.), The Reception of Continental Reformation in Britain (Oxford: Oxford University Press, 2010), p. 40.

3 Cranmer's Homilies and Erasmus' Paraphrases: Paul L. Hughes and James F. Larkin (eds.), Tudor Royal Proclamations (3 vols., New Haven: Yale University Press, 1964), I, pp. 393-403: 
Bible, became the canonical texts of the Edwardian church. The political and religious elite initiated the reformation, and the newly-empowered evangelical faction pressed its advantage.

Print played a central role in this process. The regime sponsored specific printers by creating official positions and issuing patents and privileges. The religious policies of the regime also facilitated wider growth in the industry by creating a climate of evangelical freedom, which allowed printers to produce an outpouring of reformist tracts. English printing grew disproportionately during Edward's tenure. Every Edwardian year saw more titles printed than in any Henrician year and total output throughout the reign, 1212 titles, almost doubled that of the preceding seven-year period. ${ }^{4}$ The canonical church publications played a critical role not only in underpinning the regime's religious policies but also in stimulating the print industry. ${ }^{5}$ By examining these publications in the context of print production, this essay establishes their importance as investments by the crown and as financing for a select few of England's printers.

It has been well established that England's reformers were committed to using print to spread evangelicalism. ${ }^{6}$ Just as the wider European movements for reform used the printing press to spread their protestations against the Roman Catholic Church and to spread their theologies, England followed suit. ${ }^{7}$ Influential patrons sponsored polemical literature, and the regime facilitated growth in the industry by openly supporting evangelicalism and choosing not to censor the printers of evangelical works. ${ }^{8}$ Printers in England responded to

31 July 1547. The Order of Communion and the Catechism: Hughes and Larkin, Tudor Royal Proclamations, I, pp. 417-418: 8 March 1548. Book of Common Prayer: 2 \& 3 Edward VI c.1; 5 \& 6 Edward vi, c.1.

4 Between 1547 and 1553, the USTC lists 1212 titles printed in England, compared to 667 titles between 1540 and 1546 . The term 'titles' is used throughout this essay in accordance with the Ustc. A 'title' represents any printed item that varies from another, see Phillip Gaskell, A New Introduction to Bibliography (Oxford: Clarendon Press, 1972), pp. 313-316.

5 Peter Marshall, Heretics and Believers: A History of the English Reformation (New Haven: Yale University Press, 2017), pp. 306-309; Craig, 'Erasmus or Calvin?', p. 40.

6 David Loades, 'Books and the English Reformation prior to 1558 ', in Jean-Francois Gilmont (ed.), Karin Maag (trans.), The Reformation and the Book (Aldershot: Ashgate, 1998), pp. 282283; Alec Ryrie, The Age of Reformation: The Tudor and Stewart Realms, 1485-1603 (London: Routledge, 2017), pp. 138-139; Catharine Davies, The Defence of the Reformation in the Reign of Edward VI (Manchester: Manchester University Press, 2002), pp. ix-x.

7 Andrew Pettegree, The Book in the Renaissance (New Haven: Yale University Press, 2010), pp. 101-104, 109, 127-129.

8 Diarmaid MacCulloch, Tudor Church Militant: Edward VI and the Protestant Reformation (London: Allen Lane, 1999), p. 7; Elizabeth Evenden, Patents, Pictures and Patronage: John Day and the Tudor Book Trade (Aldershot: Ashgate, 2008); John N. King, English Reformation 
the shift of the religious landscape with a flurry of evangelical works in these years, which increased English printed output to unprecedented levels. ${ }^{9}$ The regime also actively participated as a patron of the print trade creating the largest commissions of these years. Stephen Alford observed correctly that much of the evangelical printing in the Edwardian years was 'not necessarily a rigid and inflexible form of 'state-sponsored' print'. ${ }^{10}$ In the specific case of the canonical church documents, however, this is exactly what it was. The regime contracted these works to top-tier London printers and budding provincial printers to support the production of high-quality works and promote the expansion of printing beyond the confines of the capital.

This policy of mandatory church documents was rooted in Henrician proclamations, which had obligated every parish church to purchase the Great Bible. ${ }^{11}$ What was new under Edward vi was the extent of this policy. The regime introduced five new publications in a bid to implement religious change incrementally and universally. The indicators that these works provide of the regime's theological outlook at key moments in the reign remain disputed and create a discussion that is beyond the confines of this study. ${ }^{12}$ What is critical to this examination, however, is the scale of the production of these works and their effect upon the printing trade. The canonical church documents account for a total of sixty titles. Print runs are estimated to have numbered in the thousands, with over twenty thousand prayer books published in total. ${ }^{13}$

Literature: The Origins of the Protestant Tradition (Princeton: Princeton University Press, 1982); Peter W.M. Blayney, The Stationers' Company and the Printers of London 1501-1557 (2 vols., Cambridge: Cambridge University Press, 2013); Andrew Pettegree, 'Printing and the Reformation: the English exception', in Peter Marshall and Alec Ryrie (eds.), The Beginnings of English Protestantism (Cambridge: Cambridge University Press, 2002), pp. 157-179; Stephen Alford, Kingship and Politics in the reign of Edward VI (Cambridge: Cambridge University Press, 2002).

$9 \quad$ MacCulloch, Tudor Church Militant, p. 84; Ryan M. Reeves, English Evangelicals and Tudor Obedience, c.1527-1570 (Leiden: Brill, 2014), pp. 97-99; John N. King, 'The Book trade under Edward VI and Mary I', in Lotte Hellinga and J.B. Trapp (eds.), The Cambridge History of the Book in Britain (7 vols., Cambridge: Cambridge University Press, 1999), II, pp. 164-165.

10 Alford, Kingship and Politics in the reign of Edward VI, p. 134.

11 R.W. Heinz, The Proclamations of Tudor Kings (Cambridge: Cambridge University Press, 1976), p. 188; Hughes and Larkin, Tudor Royal Proclamations, I, pp. 296-297: 6 May 1541.

12 The major branches of the discussion on Edwardian religious change are championed by Eamon Duffy, Stripping of the Altars, Traditional Religion in England 1400-1580 (New Haven: Yale University Press, 2005), pp. 469, 472 and by MacCulloch, Tudor Church Militant, pp. 87-96.

13 Loades, 'Books and the English Reformation prior to 1558', pp. 282-283; W.K. Jordan, Edward VI: The Young King, the Protectorship of the Duke of Somerset (Cambridge, Massachusetts: Harvard University Press, 1974), pp. 158-161; Tessa Watt, Cheap Print and Popular Piety 1550-1640 (Cambridge: Cambridge University Press, 1991), p. 259; David 
Since proclamations obligated every parish church and swathes of the clergy to purchase these new publications, England's over nine thousand parishes represented a vast market. ${ }^{14}$ The new regulations also secured a scheme for payment that demanded funds be provided in equal measure by the churches and their parishioners. ${ }^{15}$ Such commands secured both consumers and funding, which allowed printers to budget more effectively. Budgeting was essential for a printer's business, since failing to estimate demand effectively could be financially disastrous. Overestimating demand could tie up capital in slow-moving or immovable stock, whilst underestimating demand might require a second print run, prompting further composition, typesetting, and proofreading. ${ }^{16}$ Official commissions, then, allowed for sustainable printing shops.

The level of popular support for the reformation under Edward vi remains a contentious historiographical issue. ${ }^{17}$ Nevertheless, parochial studies by John Craig have shown that many churchwardens complied with Henrician and Edwardian orders to purchase official books. ${ }^{18}$ In the light of this, print runs for the canonical documents were likely as large as print houses could feasibly manage. By examining the canonical church publications as products of the press, the essay seeks to highlight the level of investment made by the Edwardian government and to establish the amount of printing that was generated by this investment.

Daniell, The Bible in English: Its History and Influence (New Haven: Yale University Press, 2003), p. 245 .

14 John Craig, 'Forming a Protestant Consciousness? Erasmus' Paraphrases in English Parishes, 1547-1666', in Hilmar M. Pabel and Mark Vessey (eds.), Holy Scripture Speaks: The Production and Reception of Erasmus' Paraphrases on the New Testament (Toronto: University of Toronto Press, 2002), pp. 317-318.

15 Hughes and Larkin, Tudor Royal Proclamations, I, pp. 393-403:31 July 1547:'... the charge of which books shall be ratably borne between the parson or proprietary and the parishioners aforesaid; that is to say, the one half by the parson or proprietary and the other half by the parishioners ...'; Craig, 'Forming a Protestant Consciousness?', p. 317; Craig, 'Erasmus or Calvin?', p. 40; Susan Powell, 'The Secular Clergy', in Vincent Gillespie and Susan Powell (eds.), A Companion to the Early Printed Book in Britain, $1476-1558$ (Cambridge: D.S. Brewer, 2014), p. 172.

16 Elizabeth Evenden and Thomas S. Freeman, Religion and the Book in Early Modern England: the Making of John Foxe's "Book of Martyrs" (Cambridge: Cambridge University Press, 2011), pp. 19-20.

17 Davies, The Defence of the Reformation, pp. 231-232; Duffy, Stripping of the Altars, p. 493; Ethan H. Shagan, Popular Politics and the English Reformation (Cambridge: Cambridge University Press, 2003), pp. 270-272.

18 Craig, 'Erasmus or Calvin?', pp. 39, 44-45; Craig, 'Forming a Protestant Consciousness?', p. 325 . 


\section{The Production of the Canonical Works}

In order to establish the scale of the regime's investment in the printing trade, we must examine the canonical documents as books rather than texts. The canonical works ranged from twenty-page octavos, up to large six-hundredpage folios. The smaller works, the Homilies, the Order of Communion and the Catechisms were printed in octavo or quarto and were short, seldom illustrated and relatively straightforward printing jobs. The larger works, which are the chief focus on this essay, required far greater efforts, technical assurance and capital to be invested.

Whilst the Homilies were read aloud to parishioners, the Paraphrases and the Great Bible were both to be 'set up in some convenient place within the said church that they have cure of, whereas their parishioners may most commodiously resort unto the same, and read the same.'19 They were illustrated extensively and decorated with woodcuts, initials and a wider variety of typefaces. The Book of Common Prayer, the shortest of this list, required over three hundred pages (seventy-five sheets per copy), whilst a Paraphrases folio required at least six hundred pages (150 sheets). Printers also produced the Book of Common Prayer in smaller formats, but as churches were ordered to provide folio editions, only these can be considered canonical. By comparison, Peter Blayney's research found that the average Edwardian octavo required only 9.5 edition sheets (9.5 sheets per copy), whilst the average Edwardian book required 18.5 sheets per copy. ${ }^{20}$ The large canonical works would have been produced in bigger print runs than the smaller works to avoid the painstaking task of resetting type and printing afresh. ${ }^{21}$ Each edition would occupy presses for months at a time, particularly if its printer hoped to fulfil the enforced demand. Establishing these press times and the scale of these projects is critical to learning just how heavily the regime invested in the print trade.

It is difficult to gauge just how profitable the large canonical church documents were for the regime's printers. Although we lack archival material to establish print runs, sales and prices, some information can be gleaned from official proclamations and churchwardens' accounts. During Henry virI's reign, the maximum price for the Great Bible was enforced at 1os. unbound

19 W.H. Frere and W.P.M. Kennedy (eds.), Visitation Articles and Injunctions of the Period of the Reformation (3 vols., London: Longmans, Green \& Co., 1910), II, pp. 117-118.

$20 \quad$ Blayney, The Stationers' Company and the Printers of London, p. 833.

21 Lucien Febvre and Henri-Jean Martin, David Gerard (trans.), The Coming of the Book. The Impact of Printing 1450-180o (London: Verso, 1997), p. 216; Daniell, The Bible in English, p. 120. 
and 12s. bound. ${ }^{22}$ A similar 1549 proclamation established the maximum price for the Book of Common Prayer: unbound at 2s. 2d., bound in forel at 2s. 1od., sheepskin at 3s. 3d., and calf leather at $4 \mathrm{~s} .{ }^{23} \mathrm{~A}$ complete print run for the Great Bible, even very conservatively estimated at 1200 copies, sold entirely unbound, could retail for up to £6oo, and a print run of the Book of Common Prayer could be sold in its entirety for $£_{13} \mathrm{o}$. A larger print run of two thousand volumes could reap a final gross return of $£ 1,000$ and $£ 216$ respectively. If sold at the crown-mandated maximum prices, the folio bible could charge o.3d. per sheet unbound and $0.37 \mathrm{~d}$. per sheet for a bound edition. The Book of Common Prayer, according to the official proclamation, could be sold at $0.35 \mathrm{~d}$. per sheet for an unbound copy, or o.64d. per sheet bound in calf leather.

During Edward's reign, Yatton parish church in Somerset secured a Bible for 11s. (o.34d. per sheet), though St Alphege, London paid 26s. (o.8d. per sheet), over double the price initially allowed by the now-expired Henrician proclamation. ${ }^{24}$ The churchwardens of St Andrew Hubbard's in Eastcheap paid 4s. (o.64d. per sheet) for their copy of the second Book of Common Prayer, while St Mary, Devises paid 4s. 8d. (o.7d. per sheet). ${ }^{25}$ There was no official maximum sale price listed for Erasmus' Paraphrases, but the prices paid by the parishes of St Mary's At Hill and Boxford Suffolk (5s. each) would place the price per sheet at $0.4 \mathrm{~d}$. The churchwardens of Yatton, Somerset paid 6s. $4 \mathrm{~d}$. for their copy of the Paraphrases, taking the per sheet price over $0.5 \mathrm{~d} .{ }^{26}$ These prices indicate that the larger the book, the lower the price per sheet. This may indicate economies of scale relating to the price of paper and production, but must also reflect the same for binding costs. Frances R. Johnson's research into early modern English book prices indicated an average price of $0.45 \mathrm{~d}$. per sheet for the 156os, which sits directly between the bound and unbound prices for the Paraphrases. ${ }^{27}$

22 Hughes and Larkin, Tudor Royal Proclamations, I, pp. 296-298: 6 May 1541.

23 Hughes and Larkin, Tudor Royal Proclamations, I, pp. 464: 3 June 1549.

24 J. Charles Cox, Churchwardens' Accounts from the fourteenth century to the close of the seventeenth century (London: Methuen \& Co, 1913), p. 117.

25 Clive Burgess (ed.), 'Churchwardens' Accounts: nos 151-180', in The Church Records of St Andrew Hubbard, Eastcheap c1450-c1570 (London: London Record Society, 1999), f. 64; Cox, Churchwardens' Accounts, p. 112.

26 Henry Littlehales (ed.), 'Churchwardens' accounts: 1547-8', in The Medieval Records of a London City Church St Mary At Hill, 1420-1559 (London: Trübner, 1905), pp. 385-388; Cox, Churchwardens' Accounts, pp. 118-119; Peter Northeast (ed.), Boxford Churchwardens' Accounts, 1530-1561 (Suffolk: Boydell Press, 1982), pp. xv, 54.

27 Francis R. Johnson, 'Notes on English Retail Book-prices, 1550-1640', The Library, 5 (1950), pp. 89-9o, cited in Jennifer Winters, The English Provincial Book Trade: Booksellers 
These gross sales figures, of course, do not account for the cost of production. Printers had to account for raw materials, production overheads, staff payments, and any reduction in wholesale price to distributors and booksellers. The costs and charges of such projects are difficult to estimate, but they must be outlined where possible to establish how much work they generated and the potential for profit that they represented.

\section{Work Generated}

Pressmen of the period are estimated to have been able to complete 1250-1500 sheets, recto and verso, per day. ${ }^{28}$ Evenden and Freeman's study of John Day's Acts and Monuments establishes as a general pattern that staff in printing houses could work twelve-hour days, across a six-day working week (Monday to Saturday), amounting to seventy-two hours per week. ${ }^{29} \mathrm{~A}$ consistent six-day week could not be sustained across an entire year, though the evangelical regime did reduce the number of fast days and saints' days observed between 1547 and $15533^{30}$ The following equation allows us to estimate the number presswork days that a print run of each of the large canonical church documents would take using one press.

Days of presswork at one press $=($ print run size $\times$ sheets required per publication $)$

$$
\text { complete sheets per day }
$$

Combining these estimates and the minimum number of sheets required for folio editions of the Book of Common Prayer (75), Paraphrases (150) and a Great Bible (390) we see the following results:

Stock-Lists, c.1520-1640 (University of St Andrews, Unpublished PhD dissertation, 2012), p. 9 .

28 Pettegree, 'Printing and the Reformation', p. 159; Pettegree estimates that pressmen could produce 1,30o copies of a single sheet, recto and verso, per day, based upon Jean Francois Gilmont, 'Printers by the Rules', The Library, 6 (1980), 129-155.

29 Evenden and Freeman, Religion and the Book, pp. 12-13.

30 This has allowed Evenden and Freeman to continue the use of an average working week of 6 days and 12 hours per day. In terms of designated rest days provided by religious holidays, see Philip Williamson, Alasdair Raffe, Stephen Taylor and Natalie Mears with Lucy Bates (eds.), National Prayers: Special Worship since the Reformation (4 vols., Woodbridge: Boydell Press, 2013), I. 
TABLE 5.1 Sheets required and press time for the canonical church documents

\section{Book of Common Prayer}

\begin{tabular}{llrrrr}
$\begin{array}{l}\text { Print run } \\
\text { size }\end{array}$ & Sheets each & Total sheets & $\begin{array}{l}\text { Minimum } \\
\text { press days }\end{array}$ & $\begin{array}{l}\text { Maximum } \\
\text { press days }\end{array}$ & $\begin{array}{l}\text { Working } \\
\text { weeks }\end{array}$ \\
\hline 1200 & 75 & 90,000 & 60 & 72 & $10-12$ \\
1500 & 75 & 112,500 & 785 & 90 & $12.5-15 \cdot 5$ \\
2000 & 75 & 150,000 & 100 & 120 & $16.6-20$ \\
\hline
\end{tabular}

Erasmus' Paraphrases

\begin{tabular}{llllll}
$\begin{array}{l}\text { Print run } \\
\text { size }\end{array}$ & Sheets each & Total sheets & $\begin{array}{l}\text { Minimum } \\
\text { press days }\end{array}$ & $\begin{array}{l}\text { Maximum } \\
\text { press days }\end{array}$ & $\begin{array}{l}\text { Working } \\
\text { weeks }\end{array}$ \\
\hline 1200 & 150 & 180,000 & 120 & 150 & $20-24$ \\
1500 & 150 & 225,000 & 150 & 180 & $25-30$ \\
2000 & 150 & 300,000 & 200 & 240 & $33.2-40$ \\
\hline
\end{tabular}

Folio Bible

\begin{tabular}{llllll}
$\begin{array}{l}\text { Print run } \\
\text { size }\end{array}$ & Sheets each & Total sheets & $\begin{array}{l}\text { Minimum } \\
\text { press days }\end{array}$ & $\begin{array}{l}\text { Maximum } \\
\text { press days }\end{array}$ & $\begin{array}{l}\text { Working } \\
\text { weeks }\end{array}$ \\
\hline 1200 & 390 & 468,000 & 312 & 374.4 & $52-62.4$ \\
1500 & 390 & 585,000 & 390 & 468 & $65-78$ \\
2000 & 390 & 780,000 & 520 & 624 & $86.6-104$ \\
\hline
\end{tabular}

In presswork alone, two thousand copies of the Book of Common Prayer could feasibly occupy a single press for over four months. The requisite nine thousand copies for the realm's parish churches generated eighteen months of presswork on a single press. The Paraphrases required double the number of sheets and thus twice the presswork. Of course, expecting comprehensive production, investment and compliance from a single print run is unfeasible. One print run of nine thousand copies would tie up too much capital in immovable stock and would leave compositors idle for days at a time. Neither England's 
printers nor its reformers had this luxury. The fact that Erasmus' Paraphrases has seven variant titles, the 1549 Book of Common Prayer has thirteen, and the 1551 Book of Common Prayer has sixteen in the Universal Short Title Catalogue is suggestive of smaller print runs put together piecemeal.

Printers operated multiple presses. ${ }^{31}$ As leading printers in the English context and the primary printers of the canonical church documents, Richard Grafton and Edward Whitchurch were each likely operating between three and five presses. From a two-press print house, a 1549 Book of Common Prayer could take as few as thirty or as many as sixty press days (or between five and ten weeks) for a more conventional print run size. For the Paraphrases or a complete folio bible, the time required at the press increases significantly. If Whitchurch were running three presses concurrently on the Paraphrases project, the requisite nine-thousand copies would mean the project was at the press all year. ${ }^{32}$ The longest Edwardian folio bible, produced in 1549 by Thomas Raynald and William Hill, was 1576 pages (394 sheets). ${ }^{33}$ As smaller-scale printers, Raynald and Hill would not have been operating as many presses as Grafton or Whitchurch. Even using our lower estimate of print-run size and two presses, this bible would have required between 157 and 190 days of presswork, amounting to at least six or seven months.

Jean-François Gilmont's 'Printers by the rules' established that pressmen and compositors worked together in teams. ${ }^{34}$ Elizabeth Evenden and Thomas Freeman calculated that compositors could set seventeen lines of John Day's 1570 edition of John Foxe's Acts and Monuments per hour; a single sheet in seventeen hours and, therefore, around four sheets in a little under a working week. ${ }^{35}$ We can only use these estimates as a guide, as the typographical arrangement of all publications varied, but they offer support to our estimates. If printing a Book of Common Prayer required the setting of 75 sheets, the Paraphrases 150 sheets, and a folio bible 390 sheets, two compositors could complete the setting of these works in approximately 9-10 weeks, 18-20 weeks, and $48-56$ weeks respectively. These figures suggest that composition could be

31 Evenden and Freeman, Religion and the Book, pp. 8-9: 'In London, in May 1583, there were twenty-two printing houses, four had three presses, John Day and Henry Denham each had four presses, Christopher Barker and John Wolfe both had five presses ... Only four printing houses - fewer than one-fifth of the total - had over three presses, and only one printing house, that of Christopher Barker, the Queen's Printer had (legitimately) five presses'.

Nine-thousand copies required 1,350,00o printed sheets, which falls between 900 and 1,080 press days, spread over three presses amounting to between 300 and 360 press days.

33 USTC 504299.

34 Gilmont, 'Printers by the Rules'.

35 Evenden and Freeman, Religion and the Book, p. 19. 
completed in a comparable timeframe to the required presswork across two presses providing that print runs exceeded 1200 copies.

\section{Costs and Overheads}

The overheads for projects such as these were high. Paper was notoriously expensive and comprised a large proportion of the raw materials required. Little direct evidence for the price of paper in the English context during Edward's reign remains, though having to import paper likely raised prices beyond European norms. ${ }^{36}$

In 1550, Thomas Stanbridge sued Humphrey Powell at the King's Bench for $£_{13} 6$ s. 8d. for failing to pay for one hundred reams of 'good quality and saleable paper'. ${ }^{37}$ In the absence of other archival evidence, we can extrapolate this figure to the canonical church works to provide an estimate, with the caveat that we cannot be sure of the quality of the disputed paper. ${ }^{38}$ This figure equates to just under $32 \mathrm{~s}$. per ream (one ream $=500$ sheets), or o.o6d. per sheet. Whilst Powell's was 'good quality' paper, it is likely that our printers purchased paper of higher quality but also that they enjoyed some scale advantages by purchasing such large quantities. Fewer than ten of Powell's titles printed before this court case survive, many of which were short octavos. Grafton and Whitchurch, meanwhile, were highly productive and proficient veterans of the trade and were printing these canonical works on behalf of the Church and Crown. ${ }^{39}$

At the price of paper paid by Powell, two thousand copies of the 1549 Book of Common Prayer (150,ooo sheets of paper) would require three hundred reams, and thus over $£_{40}$ of investment in paper alone. Using the maximum sales price outlined in the Edwardian proclamation of 3 June 1549 (unbound for 25. $2 \mathrm{~d}$.), this same print run could ultimately net a total of up to £216 13s. $4 \mathrm{~d}$. This paper cost accounts for less than twenty per cent of the gross retail of the book. With the quality of paper required for these works in mind, it is reasonable to

36 Febvre and Martin, The Coming of the Book, p. 112 states that in 1543 Paris paper cost between 10 and 30 sols per ream; Evenden and Freeman, Religion and the Book, p. 10; Pettegree, 'Printing and the Reformation', p. 159.

37 Blayney, The Stationers' Company and the Printers of London, p. 614.

38 Unfortunately, none of Humphrey Powell works could be examined at the Huntington to compare paper quality.

39 Blayney, The Stationers' Company and the Printers of London, p. 670. Blayney lists Whitchurch then Grafton as producing the most edition sheets of the reign. 
expect that the outlay on paper absorbed between twenty and thirty per cent of the total gross returns for the Book of Common Prayer. ${ }^{40}$

A second outlay that we must consider is wages. At least seven individuals were required to run two presses in this period: two pressmen and one compositor per press and a single corrector. During the mid-sixteenth century, Christopher Plantin's presses averaged four and a half individuals to a press, before reducing this number to four or fewer after $1566 .{ }^{41}$

Henry Wansborough estimated the income of an average labourer during this period as approximately 6s. per week, whilst the National Archives predict the wage of a skilled labourer in $155^{\circ}$ at 4 s. per week. ${ }^{42}$ These figures must form only the minimum benchmark for our calculations. Compositors and correctors needed sufficient education in order to read the texts that they worked on, and the canonical texts required more aptitude than an average text. Evenden and Freeman have claimed that these requisite skills would have allowed print house workers to secure higher salaries, though they have not provided a reasonable expectation for what this might be. ${ }^{43}$ If we take the higher estimate as a pressman's wage and increase pay by one third for compositors and correctors, we have a conservative weekly running cost of 28 s. for four workers of a single press, and 48s. for seven individuals working two presses.

In order to understand the economic realities associated with these projects, we can compare potential gross revenue against the estimated outlay on paper and wages. These figures highlight how expensive paper was. Our minimum estimates show the cost of paper for any of these publications amounts to almost double the labour costs. Nonetheless, the total cost of these two major contributing expenses represents only one-third of the anticipated retail value of the print run.

The calculations above consider only the costs of creating these specific works and do not include operational costs. ${ }^{44}$ One substantial outlay was the

40 Jean-François Gilmont, Bibliographie des éditions de Jean Crespin, 1550-1572 (2 vols., Verviers: Librairie P.M. Gason, 1981) I, p. 54 cited in Evenden and Freeman, Religion and the Book, p. 10: Gilmont estimated forty per cent of the cost of the book.

41 Gilmont, 'Printers by the rules', p. 154.

42 Henry Wansbrough, 'History and Impact of English Bible Translations', in Magne Sæbo (ed.), Hebrew Bible/ Old Testament: The History of Its Interpretation (5 vols., Göttingen, Vandenhoeck \& Ruprecht, 2008) II, p. 548; The National Archives maintains 4s. was six days wages for a skilled labourer from 1500-1570, changing only in 1580 at [http://www .nationalarchives.gov.uk/currency-converter/, Accessed 24 November 2018].

43 Evenden and Freeman, Religion and the Book, p. 11.

44 Churchwarden accounts for compliance with the demands to purchase and for prices paid for the canonical church documents would offer clearer information here. Information 
TABLE 5.2 Paper and wage costs for the canonical church documents

\begin{tabular}{|c|c|c|c|c|c|c|c|c|}
\hline Title & $\begin{array}{l}\text { Print } \\
\text { run size }\end{array}$ & $\begin{array}{l}\text { Maximum } \\
\text { gross retail }\end{array}$ & $\begin{array}{l}\text { Paper } \\
\text { costs }\end{array}$ & $\begin{array}{l}\text { Paper } \\
\text { (sheets) }\end{array}$ & $\begin{array}{l}\text { Wages } \\
\text { per week }\end{array}$ & $\begin{array}{l}\text { Press } \\
\text { days } \\
2 \text { presses }\end{array}$ & $\begin{array}{l}\text { Weeks } \\
\text { required }\end{array}$ & $\begin{array}{l}\text { Total } \\
\text { wages }\end{array}$ \\
\hline $\begin{array}{l}\text { Book of } \\
\text { Common }\end{array}$ & 1200 & $£_{13} 0$ & $£ 24$ & 9०,००० & $48 s$. & $3^{0}-36$ & $5^{-6}$ & $\begin{array}{l}£ 12-£ 14 \\
8 \mathrm{~s} .\end{array}$ \\
\hline Prayer & 2000 & $£ 215$ & $£ 40$ & $15^{0,000}$ & $48 s$. & $5^{\circ-6 o}$ & $9-10$ & $\begin{array}{l}£ 21 \\
125 .-£ 24\end{array}$ \\
\hline \multirow[t]{2}{*}{$\begin{array}{l}\text { Para- } \\
\text { phrases }\end{array}$} & 1200 & $\mathrm{n} / \mathrm{a}$ & $£ 48$ & 180,000 & $48 s$. & $60-72$ & $10-12$ & $\begin{array}{l}£ 24-£ 28 \\
16 \mathrm{~s} .\end{array}$ \\
\hline & 2000 & $\mathrm{n} / \mathrm{a}$ & $£ 80$ & 300,000 & $48 s$. & $100-120$ & $18-24$ & $\begin{array}{l}£ 43 \text { 4s.- } \\
£ 57 \text { 12s. }\end{array}$ \\
\hline \multirow[t]{2}{*}{$\begin{array}{l}\text { Folio } \\
\text { Bible }\end{array}$} & 1200 & $£ 600$ & $£ 124$ & 468,ooo & $48 s$. & $15^{6-188}$ & $26-32$ & $\begin{array}{l}£ 62 \text { 8s.- } \\
£_{76.16 \mathrm{~s}}\end{array}$ \\
\hline & 2000 & $£ 1$, o०o & $£ 208$ & 780,000 & $48 s$. & $260-307$ & $44^{-51}$ & $\begin{array}{l}£ 105 \\
12 \mathrm{~s} .- \\
£ 1228 \mathrm{~s} .\end{array}$ \\
\hline
\end{tabular}

rent of premises. Rising publisher William Seres paid $£ 4$ per annum to lease his St Paul's churchyard property in 1549 , with the option to purchase at $£ 8$, whilst a record for Grafton's printing house rent remains for 1562, which stood at $£ 6$ 13s. $4 \mathrm{~d} .{ }^{45}$ Presses also had to be maintained, and those printers who commissioned new type and illustrations had to pay accordingly. Type was often imported from the continent, and this remained an area where England represented a small part of a wider European book world. ${ }^{46}$ Printing

on payments for type, illustrations and staff wages would also offer more clarity, but little has survived in archival material in the English context.

45 Blayney, The Stationers' Company and the Printers of London, p. 1003; Carol Kazmierczak Manzione, Christ's Hospital of London, 1552-1598, "A Passing Deed of Pity" (Selinsgrove: Susquehanna University Press, 1995), p. 133.

46 Pamela Robinson, 'Materials: Paper and Type', in Gillespie and Powell (eds.), A Companion to the Early Printed Book in Britain, p. 71; A.F. Johnson, cited in 'Printing in England from William Caxton to Christopher Barker, An Exhibition: November 1976-April 1977', Virtual Exhibitions of Special Collections material, at [http://special.lib.gla.ac.uk/exhibns/ printing/, Accessed 12 November 2018]; Elizabeth Evenden, Patents and Patronage: the Life and Career of John Day, Tudor Printer (University of York, Unpublished PhD dissertation, 2002), p. 129 . 
houses added to their type and illustration stock incrementally, which meant that investment could vary dramatically year-on-year. They also reduced their prices to book wholesalers, who had to make a profit. With all of these factors to account for, printers needed to maintain a significant margin between paper and wage costs and retail price. Nonetheless, these figures suggest a potential mark-up of some sixty to seventy per cent possible between the cost of paper and wages and the final retail price of the canonical church documents. These works, whilst incredibly demanding to produce, generated vast amounts of presswork and injected substantial capital into the trade.

Few, if any, printing projects were comparable to the larger canonical church documents in the Edwardian period. By creating these projects, the Crown and the Church of England were leading patrons of the English book world. There were bigger publications in the period, including Nicolas Hill's folio editions of The Workes of Chaucer (1550) and the bible (1551), each printed for a syndicate of publishers based around Paul's Cross. ${ }^{47}$ However, without the huge crown-enforced demand underpinning Hill's projects, print runs were likely far closer to industry convention. If Hill produced two thousand copies of his Bible, the Paraphrases project would have required more sheets and presswork, providing Whitchurch fulfilled at least sixty per cent of the mandated demand.

In 1550, John Day printed five works by Thomas Becon in octavo. ${ }^{48}$ Becon's lure as an author was sufficient for Day to secure a patent for the printing of his works on 25 March $1553 \cdot{ }^{49}$ These five publications combined required one hundred sheets, or just two-thirds of the paper needed for Whitchurch's Paraphrases. ${ }^{50}$ Providing that Whitchurch produced enough copies for even

47 Editions of The works newly printed of Chaucer: (London: Nicolas Hill for Richard Kele, 1550), USTC 504408; (London: Nicolas Hill for Thomas Petyt, 1550), USTC 504409; (London: Nicolas Hill for William Bonham, 1550), UsTC 504415; (London: Nicolas Hill for Robert Toy, 1550), UstC 504436; Editions of The Byble: (London: [Nicolas Hill] for Thomas Petyt, 1551), (London: [Nicolas Hill] for Thomas Petyt, 1551), USTC 504570; (London: John Wight, 1551), USTC 504643; (London: Robert Toy, 1551), USTC 504644; (London: John Walley, 1551), USTC 515045; (London: [Nicolas Hill] for William Bonham, 1551), USTC 518678; (London: [Nicolas Hill], at the cost of Richard Kele, 1551), USTC 518679; (London: Nicolas Hill for Abraham Veale, 1551), USTC 518466.

48 Day printed The fortress of the faithful, USTC 504365, 504383, The flour of godly praiers, USTC 504369, The jewel of joye, USTC 504392, The principles of Christen religion, USTC 516002, and The governans of virtue, USTC 518397.

49 Calendar of Patent Rolls Preserved in the Public Record Office (5 vols., London: H.M. Stationery Office, 1924-1926), v, p. 43.

$5^{\circ}$ Day's edition of The governans of vertue exists only in fragments, but his 156o sextodecimo edition of the same work survives, USTC 505709. In the absence of the 1550 edition, the sheet count from the 156 o edition has been used. 
half of the parish churches, Day would have had to have printed over six thousand copies of each Becon edition in order for the projects to be of a comparable scale. Indeed, the nine thousand copies of the Paraphrases represent a total sheet count that would exceed five hundred copies of every work printed or published by John Day during the reign. ${ }^{51}$

Without the regime's support, even the most ambitious printer would surely have printed far fewer copies of the canonical works than Whitchurch did. The significance of the regime's role is difficult to understate. These projects were created and supported by those at the heart of the regime and their policy to house a copy in every parish church made the English Church and Crown critical investors in English printing.

\section{The Official Printers of Canonical Church Documents}

Four printers were permitted to print the canonical documents of the Edwardian Church. The regime issued patents to Richard Grafton and Edward Whitchurch (22 April 1547), John Oswen (7 January 1549) and Humphrey Powell (18 July 1550) to ensure that these works would be circulated widely across Edward's kingdom. ${ }^{52}$ In order to establish how far the canonical church documents went to initiate growth or prosperity, we must consider the printers themselves. This section will highlight that, in specific circumstances, the canonical church documents could underpin thriving printing enterprises.

As Table 5.3 shows, the canonical documents were largely the preserve of Richard Grafton and Edward Whitchurch. These printers worked closely together throughout the period, and they represent the top tier of English printing hierarchy throughout the 1540 os $^{53}$ Grafton and Whitchurch were already in receipt of royal support prior to Edward's accession. They were recruited by Thomas Cromwell to produce the 'Matthew' Bible in 1537 and, with their proficiency proven, they stewarded the production of the

$51 \quad$ Between 1550 and 1553, John Day printed or published seventy-two works in London. Day produced the overwhelming majority of his works as octavos, which ensures the sheet count is significantly reduced. Among Day's works in this period, there was only one folio (USTC 504663). Peter Blayney records 219o edition-sheets contributed by Day, for which five hundred copies of each would require 1.1 million sheets, whilst the nine thousand Paraphrases copies would require 1.3 million sheets; Blayney, The Stationers' Company and the Printers of London, p. 667.

52 Patent Rolls Edward VI, I, p. 100, 269; John Roche Dasent etc. (eds.), Acts of the Privy Council of England (46 vols., London: H.M. Stationery Office, 189o-1964), III, p. 84.

53 Lotte Hellinga, 'Printing', in Hellinga and Trapp (eds.), The Cambridge History of the Book in Britain, III, pp. 105-106. 
TABLE 5.3 The patent-holding printers of the canonical church documents

\begin{tabular}{lll}
\hline Printer & Title & Total number of titles \\
& & \\
\hline Richard Grafton & Homilies & 4 \\
& Order of the Communion & 2 \\
& Catechism & 1 \\
& Paraphrases & \\
& 1549 Book of Common Prayer & 6 \\
& $155^{2}$ Book of Common Prayer & 9
\end{tabular}

\begin{tabular}{|c|c|c|}
\hline Edward Whitchurch & Homilies & 5 \\
\hline & Order of the Communion & \\
\hline & Catechism & \\
\hline & Paraphrases & 8 \\
\hline & 1549 Book of Common Prayer & 5 \\
\hline & $155^{2}$ Book of Common Prayer & 10 \\
\hline John Oswen & Homilies & 1 \\
\hline (Worcester) & Order of the Communion & \\
\hline & Catechism & \\
\hline & Paraphrases & \\
\hline & 1549 Book of Common Prayer & 2 \\
\hline & $155^{2}$ Book of Common Prayer & 1 \\
\hline Humphrey Powell & Homilies & \\
\hline (Dublin) & Order of the Communion & \\
\hline & Catechism & \\
\hline & Paraphrases & \\
\hline & 1549 Book of Common Prayer & \\
\hline & $155^{2}$ Book of Common Prayer & 1 \\
\hline
\end{tabular}

a The sixty titles in question include the fifty-five listed as being printed by four official patent holders shown in table 5.3 along with titles by non-patent holders with single titles of the Order of the Communion printed by John Day (1548), Thomas Raynald and William Hill (1548), two Catechisms by Nicolas Hill for Gwalter Lynne (1548) and a folio Great Bible by Stephen Mierdman (1553). 
inaugural Great Bible in 1539. The Great Bible project led to nine folio titles during Henry's reign. ${ }^{54}$ Grafton and Whitchurch also received a patent for the printing of English service books and the English Primer in 1545, which was renewed swiftly under Edward vi and validated for another seven years. ${ }^{55}$ They became the printers of choice for the Edwardian Church and Crown: one of these two names appeared on fifty of the sixty total canonical church documents, and one of these two individuals printed at least one edition of each qualifying publication. The regime's chosen printers produced no Great Bible folios under Edward's rule, which suggests a high level of compliance with the Henrician regulations. ${ }^{56}$ This high compliance must have been a valuable precedent when beginning work on the new canonical documents.

The roles undertaken by printers of official church works made them confidants of the regime. By necessity, each had access to draft copies and printers' sheets prior to their release. This is particularly noteworthy between 1547 and 1553, as Edwardian religious change occurred rapidly and was contested consistently. The 1549 Book of Common Prayer, after all, had led to rebellion and contributed to the fall of the Duke of Somerset. In 1552, the Council reminded Grafton of his obligations, demanding that he 'stay in any wyse from uttering any of the bookes of the Newe Service and ... not to put any of them abrode untill certaine faultes therein be corrected'. ${ }^{57}$ Given the hostile reception of the 1549 Book of Common Prayer, and the 'black rubric' controversy surrounding the $155^{2}$ Book of Common Prayer even prior to its release, this confidentiality clause is of particular importance. ${ }^{58}$ Cyndia Susan Clegg's examination of the first Elizabethan Book of Common Prayer has uncovered a draft copy for

54 Daniell, The Bible in English, pp. 200-203 suggests that there was a transfer of staff along with materials in this repatriation process in the 1540s; USTC 503073, 503272, 503237, 5०3234, 503235, 503153, 503233, 518561, 5०3151.

Tamara Atkin and A.S.G. Edwards, 'Printers, Publishers and Promoters to 1558', in Gillespie and Powell (eds.), A Companion to the Early Printed Book in Britain, p. 39; Peter Blayney, 'William Cecil and the Stationers', in Robin Myers and Michael Harris (eds.), The Stationers' Company and the Book Trade 1550-1990 (Winchester: St Paul's Bibliographies, 1997), p. 15.

56 Alec Ryrie, 'Counting sheep, counting shepherds: the problem of allegiance in the English Reformation', in Peter Marshall and Alec Ryrie (eds.), The Beginnings of English Protestantism (Cambridge: Cambridge University Press, 2002), p. 88; Ronald Hutton, 'Local Impact of the Tudor Reformations', in Christopher Haigh (ed.), The English Reformation Revised (Cambridge: Cambridge University Press, 1987), p. 118.

57 Dasent, Acts of Privy Council, IV, p. 131: 27 September 1552.

$5^{8}$ MacCulloch, Tudor Church Militant, p. 10o; John N. King, 'Paul's Cross and the implementation of Protestant Reforms under Edward VI', in W.J. Torrance Kirby and P.G. Stanwood (eds.), Paul's Cross and the Culture of Persuasion in England, 1520-1640 (Leiden: Brill, 2013), p. 142. 
parliamentary use, which originated as an Edwardian print run produced by Richard Grafton. ${ }^{59}$ With religious policy developing so quickly under Edward, there was scope for small-batch printing when documents were under revision. Clegg's study has also made clear that variant issues made up of different pieces of existing stock joined with freshly printed material were in limited circulation. Editions such as these suggest that Grafton's workshop produced even more official print than is included in short title catalogues.

Edward Whitchurch was the most prolific printer of the canonical church documents. They were a core component of his output, making up twentyeight of his total eighty-eight publications, including at least one in six of the seven years in which Edward reigned. His canonical output focused on larger volumes: five quarto titles of Cranmer's Homilies, eight folio titles of Erasmus' Paraphrases; five folio 1549 Books of Common Prayer; and ten $155^{1}$ Books of Common Prayer (seven folios, two quartos and one octavo). ${ }^{60}$ The scale of these projects had a marked impact on Whitchurch's opportunities to engage in other projects. In 1547, the only canonical church document from Whitchurch's presses was Cranmer's Homilies. This work required 16o quarto pages on average, which was a significant but manageable project, particularly as Grafton's presses were also printing the same work to fulfil demand. This allowed him to complete a 672-page octavo New Testament in the same year. ${ }^{61}$ By contrast, in 1548, Whitchurch printed the inaugural edition of Paraphrases without Grafton's help. Fulfilling church demand would have been a daunting task and Whitchurch curtailed his other projects accordingly. He produced psalters, a catechism, and Catherine Parr's Lamentations of a Sinner, each fewer than 275 octavo pages (eighteen sheets). ${ }^{62}$ In the following two years, Whitchurch's attention to the canonical church documents varied dramatically. In 1549, he produced eighteen titles in total, including five of the Book of Common Prayer, a quarto bible, and the second volume of Erasmus' Paraphrases. In 1550, without any canonical works to print, his total output fell to fifteen titles, but he was able to focus upon a large folio of Giovanni de Vigo's The Most Excelent

59 Cyndia Susan Clegg, 'The 1559 Books of Common Prayer and the Elizabethan Reformation', Journal of Ecclesiastical History, 67 (2016), pp. 94-121. This work would have fallen under Grafton's remit of King's Printer for Statutes \& c. as it was not released for general service use.

6o Blayney, The Stationers' Company and the Printers of London, pp. 684-685, Blayney describes the misleading 'repetitive dating' provided in Whitchurch's Paraphrases publications which account for matching publication dates.

61 USTC 51645 o.

62 USTC 5O3922, 5०3943, 5०3984, 5०3996, 504091, 515966, 51856o, 5०4134, 5०4135. 
Worckes of Chirurgery and an octavo edition of Jean Calvin's Geneva Book of Common Prayer. ${ }^{63}$

Whitchurch's business followed and supported the regime's religious policies; if he had new canonical church documents to print, he shaped his business around them, and if not, he was free to explore other commercial ventures. As the canonical document projects became less prominent as the reign developed, Whitchurch built a strong core of publications by adding the lucrative metrical psalters by Thomas Sternhold. ${ }^{64}$

Unlike Whitchurch, Richard Grafton was awarded a formal office by the regime. From 1545, Grafton had been styled 'Printer to the Princes Grace', and he was elevated to 'King's printer of all books of statutes, acts, proclamations, injunctions and other volumes issued by the king' on 17 April 1547.65 This office underpinned Grafton's business, accounting for over half of his over two hundred total titles between 1547 and 1553. The separate church service books patent he shared with Whitchurch was also of great importance. Of the sixty canonical church document titles, twenty-two came from Grafton's presses. ${ }^{66}$ The staggered release of these works ensured a steady flow of publications, and thus progress for both Edward's reformation and Grafton's business. These twenty-two titles combine with Grafton's 112 publications as King's printer of statutes \&c. to account for sixty-four per cent of his total Edwardian output. Grafton's publications were crucial for the regime, and his service book patent was crucial for his business.

Grafton's official commissions directly affected his opportunities to embark upon other substantial projects. Grafton's largest independent project of the reign was Edward Hall's Chronicle, which he produced in both 1548 and $1550 .{ }^{67}$ The 1548 edition was a fine 1168-page publication executed to a very high standard. Only in a year when Grafton was not taking on a substantial church work could he have completed such a project. During the first year of the reign, Grafton busied his presses with activities relating to his appointment as the King's printer of all books of statutes \&c. However, in 1548, his presses were free as Whitchurch completed the Paraphrases project alone. It is no coincidence

63 USTC 504548, 504424. Whitchurch had produced The Excelent Worckes of Chirurgery in 1543 , USTC 503456 .

64 Thomas Sternhold's metrical psalms are believed to have been printed by Whitchurch first in 1549 ( 3 titles), followed by 1551 ( 3 titles), $155^{2}$ (1 title), 1553 ( 5 titles).

65 Patent Rolls Edward VI, I, p. 187.

66 Three quarto and one octavo edition of the Homilies; five folios and one quarto of the first Book of Common Prayer; ten folios of the second Book of Common Prayer; four quartos of the Order of Communion; and one quarto Church of England Catechism.

67 USTC 504075, 504077, 504475, 517734. 
either that Grafton completed his second Chronicle edition in 1550, the year between the successive Book of Common Prayer projects.

These two printers served the evangelical regime devotedly, and the canonical church documents took priority over all other projects. In 1550, with the first Book of Common Prayer and Paraphrases projects behind them and with no canonical works to produce, both printers were in a position to take on ambitious private projects. This indicates not only that the lack of church works freed their presses but also that the profits allowed them to expand other avenues of their business.

\section{The Regional Alternatives}

Grafton and Whitchurch did not hold a monopoly on Edwardian Church works. The regime supported two provincial printers in an attempt to disseminate official print in areas less readily served by the London industry. Edwardian printing was overwhelmingly concentrated in London, with over ninety-five per cent of printing occurring in the capital. ${ }^{68}$ This centralisation was a distinctive characteristic of the sixteenth-century English book world, where provincial printing efforts had consistently failed to make inroads.

In spite of this, the evangelical establishment believed that provincial printers could play a role in the battle for religious uniformity. In 1549, John Oswen, who had recently relocated his Ipswich press to Worcester, was entrusted with the publication of church and service books for Wales and the Marches. The Crown also supported Humphrey Powell, paying his relocation costs to Ireland and granting him the right to print church documents. These patents led John N. King to create and confer titles of 'King's Printer for Wales' and 'King's Printer for Ireland' upon Oswen and Powell, respectively. ${ }^{69}$ However, these titles overstate the privileges they received as official appointments. The printing of service books attached a legitimacy and prestige to these provincial printers but did not amount to an official post comparable to the one held by Richard Grafton. For Oswen and Powell, the canonical church documents represented a comparatively small number of works as their total print output remained small. The historical significance of these patents, however, far outstrips this output. The regime granted them believing in the power of print to expedite religious change in resistant provinces. Both Ireland and the South

68 Provincial printing occurred in four locations under Tudor rule during Edward's reign: Ipswich (1548), Canterbury (1549-1553), Worcester (1549-1553) and Dublin (1550).

69 King, English Reformation Literature, p. 102. 
West had resisted the evangelical religious change early in the reign, and the regime underwrote these works to promote evangelical printing.

John Oswen printed defiantly evangelical works. He produced polemic by Jean Calvin, Antoine de Marcourt, and Peter Moone from Ipswich in $1548 .{ }^{70}$ Following his relocation to Worcester in 1549 , he continued in this vein, producing works by Henry Hart, John Hooper, Thomas Lever, Matteo Gribaldi, and Heinrich Bullinger and Huldrych Zwingli. ${ }^{71}$ The canonical church documents account for only four of Oswen's thirty-one titles printed during the Edwardian years, one edition of the Homilies (1549), two titles for the 1549 Book of Common Prayer and one edition of the $155^{2}$ Book of Common Prayer. The canonical church documents were not the mainstay of Oswen's business, but these works account for a substantial portion of his works. By sheet count, the Book of Common Prayer projects represent three of the four largest books produced by Oswen in Worcester, surpassed only by his 1550 quarto New Testament project. ${ }^{72}$

Oswen also used his service book patent to print more widely, including a quarto Great Bible Psalter (1549) and two quarto New Testaments (1550). This privilege highlights that the regime encouraged Oswen's provincial press to act as a bastion of evangelicalism in a social and commercial hub of the traditionally conservative South West and Wales. ${ }^{73}$ This region was under the watchful eye of the regime, which soon radically reshuffled the episcopal landscape, depriving conservative bishops and installing evangelicals in their stead. ${ }^{74}$ The reward Oswen received was his privilege, which helped to create a sustainable enterprise founded upon polemic and canonical publications.

7 USTC 503961, 5O3962, 503983, 503994, 504049, 504059, 5 O4O92.

71 USTC 504255, 504629, 504912, 504674, 504445, 504577, 504582, 504545, Gribaldi was an Antitrinitarian, but Oswen's publication of Bullinger's anti-radical tracts may have saved his standing with the regime. Cyndia Susan Clegg, "The authority and subversiveness of print' in Leslie Howsam (ed.), The Cambridge Companion to the History of the Book in Britain (Cambridge: Cambridge University Press, 2015), p. 133.

72 The Book of Common Prayer projects required 264 and $35^{2}$ pages, respectively (or sixtysix and eighty-eight sheets), while the $155^{\circ}$ New Testament required $73^{2}$ pages (or ninetytwo sheets).

73 Robert Tittler, Townspeople and Nation: English Urban Experiences 1540-1640 (Stanford: Stanford University Press, 2001), pp. 19-22, 30 states Worcester was a provincial centre rather than a provincial capital.

74 The bishoprics of Gloucester and Worcester were united under John Hooper, Miles Coverdale was awarded the see of Exeter, Robert Ferrar (a former chaplain to Lord Protector Somerset) was awarded St David's, and John Harley (a former royal chaplain-in-ordinary) was consecrated Bishop of Hereford. See Barrett L. Beer, 'Episcopacy and Reform in MidTudor England', Albion, 23 (1991), pp. 231-252. 
The privilege issued to Humphrey Powell in $155^{\circ}$ to produce official church works in Ireland had similar motivations behind it but proved less fruitful. Powell, who began his career in London, produced eleven titles between 1548 and 1550 from his shop in Middlesex. ${ }^{75}$ It is not known why Powell was chosen as the printer to relocate to Ireland, but the Acts of Privy Council show a $£_{20}$ contribution made on 18 July $155^{\circ}$ towards his setting-up costs. ${ }^{76}$ Powell's patent was tied to this relocation, and his press produced the inaugural, and only surviving, Irish imprint of the reign: a $155^{2}$ Book of Common Prayer. Powell appears to have continued life in Ireland; he printed $A$ brief declaration of certain articles of religion in 1566, though no other publications from his press have are recorded in the USTC. ${ }^{77}$

Ireland remained an unwilling participant in the Reformation. ${ }^{78}$ On 26 August 1552, Archbishop Cranmer wrote to William Cecil that 'though in Englande there bee mannye meete men for th'archbushoprickes of Irelaunde, he knows very few who would be persuaded to go thither' and bishops of Ireland consistently complained of accusations of heresy. ${ }^{79}$ With clergymen unwilling to accept relocation to Ireland, it seems an undesirable assignment for a businessman hoping to profit from selling evangelical church documents. Conservative resistance was difficult to subdue in Ireland, and the regime supported Humphrey Powell's relocation in a bid to do exactly that. Whilst only short-lived and seemingly unsuccessful, Powell's funding offers insight into the regime's perception of the importance of the printed word.

The Edwardian government supported provincial presses in locations where evangelicalism faced significant opposition. The dispensations they provided were expected to play a role in supporting the printers' enterprises and the

75 A.F. Pollard, 'Powell, Humphrey (d. in or after 1566)', rev. Anita McConnell in ODNB, available online at http://www.oxforddnb.com/view/article/2265o, (Accessed 3 May 2018).

76 Dasent, Acts of Privy Council, III, p. 84.

77 USTC 506501.

78 Peter Marshall, The Oxford Illustrated History of the Reformation (Oxford: Oxford University Press, 2015), p. 187.

79 T.J.J. Cartwright, James Macmullen Rigg, and Sophia Crawford Lomas (eds.), Calendar of the Manuscripts of Marquis of Bath preserved at Longleat, Wiltshire (5 vols., London: H.M. Stationery Office, 1907), II, pp. 11-15: 26 August 1552: Thomas, Archbishop of Canterbury to Sir William Cecil; John Strype (ed.), Ecclesiastical memorials relating chiefly to religion, and the reformation of it, and the emergencies of the Church of England, under King Henry VIII, King Edward VI and Queen Mary (3 vols., Oxford: Clarendon Press, 1822), II, pp. 905-1035; Hans Claude Hamilton (ed.), Calendar of State Papers relating to Ireland of the reigns of Henry VIII, Edward VI, Mary and Elizabeth 1509-1573 (London: H.M. Stationery Office, 186o), p. 96: December 1548: Edward Staple, Bishop of Meath to [unknown]. 
presses, in turn, were expected to support the regime. The establishment saw more profitable results in terms of both print and preaching in the South West and Wales than in Ireland. ${ }^{80}$ This policy incentivised relocation to these two provincial markets but, in terms of galvanising growth in the print industry, the canonical church documents provided little work. Successful print houses required access to extensive distribution networks and, more importantly, a large, active and literate population. Oswen and Powell's locations and patent terms limited these factors and thus their potential for growth. Nonetheless, the regime's support of these presses once again highlights the Edwardian regime as an active participant in the print world. The canonical documents were a central policy in the Edwardian reformation, and the regime was willing to support Oswen's business and establish Powell's Ireland enterprise in a bid to achieve its reformation.

\section{Conclusion}

The canonical church documents were key publications of the Edwardian reformation, created to strengthen evangelicalism in England. The regime prompted the largest printing projects of the period, owing to their policy to mandate purchase by, at minimum, every parish church in the realm. This essay has outlined how these projects injected significant capital into the book trade and generated months of presswork. The Paraphrases project alone might have occupied three to four presses for an entire year to fulfil the demand that was created. This project represented more work than many print houses completed during the entire reign.

These works were central to the output of the regime's chosen printers, Richard Grafton and Edward Whitchurch, who responded to their commissions with some of the finest printed editions of the period. By ensuring funding and buyers, the regime kept their printers' presses profitable, which also laid sound financial foundations for Grafton and Whitchurch to expand their businesses. Whilst Humphrey Powell and John Oswen also received official support, their enterprises were less successful. Limited by operating from smaller provincial centres with fewer readers, these newcomer provincial printers were swimming against strong currents. Oswen achieved some success, but these commercial factors limited his chance to grow a large business.

8o Ben Lowe, Commonwealth and the English Reformation: Protestantism and the Politics of Religious Change in the Gloucester Vale 1483-1560 (Farnham: Ashgate, 2010), Chapters 7 and 8. 
Despite challenging economic conditions, the Edwardian years represented a period of prosperity for the English book trade. The regime instigated some of this advancement through the canonical documents. Grafton and Whitchurch were England's preeminent printers, printing the most sheets and arguably the best-quality works of the reign. This productivity and production quality were linked directly to these canonical works, which demanded much from their print houses, but also helped to secure their success and fund other private projects. 